OPEN ACCESS

Edited by:

Miroslav Obornik

Institute of Parasitology (ASCR),

Czechia

Reviewed by:

Hsing-Juh Lin,

National Chung Hsing University,

Taiwan

Jutta Papenbrock

Leibniz University Hannover, Germany

*Correspondence:

Xiaoping Huang

xphuang@scsio.ac.cn

${ }^{\dagger}$ These authors have contributed equally to this work

Specialty section:

This article was submitted to Marine Molecular Biology and Ecology,

a section of the journa Frontiers in Marine Science

Received: 23 January 2020 Accepted: 12 March 2020

Published: 17 April 2020

Citation:

Jiang Z, Huang D, Fang Y, Cui L,

Zhao C, Liu S, Wu Y, Chen Q,

Ranvilage CIPM, He J and Huang $X$ (2020) Home for Marine Species: Seagrass Leaves as Vital Spawning

Grounds and Food Source.

Front. Mar. Sci. 7:194.

doi: 10.3389/fmars.2020.00194

\section{Home for Marine Species: Seagrass Leaves as Vital Spawning Grounds and Food Source}

\author{
Zhijian Jiang ${ }^{1,2,3,4 t}$, Delian Huang ${ }^{5 t}$, Yang Fang ${ }^{1,2}$, Lijun Cui ${ }^{1,2}$, Chunyu Zhao ${ }^{1,2,6}$, \\ Songlin Liu ${ }^{1,3,4}$, Yunchao Wu ${ }^{1,3,4}$, Qiming Chen ${ }^{1,2}$, \\ Chanaka Isuranga Premarathne Maha Ranvilage ${ }^{1,2}$, Jialu He $\mathrm{H}^{1,2}$ and Xiaoping Huang 1,2,3,4* \\ ${ }^{1}$ Key Laboratory of Tropical Marine Bio-resources and Ecology, South China Sea Institute of Oceanology, Chinese Academy \\ of Sciences, Guangzhou, China, ${ }^{2}$ University of Chinese Academy of Sciences, Beijing, China, ${ }^{3}$ Southern Marine Science \\ and Engineering Guangdong Laboratory, Guangzhou, China, ${ }^{4}$ Innovation Academy of South China Sea Ecology \\ and Environmental Engineering, Chinese Academy of Sciences, Guangzhou, China, ${ }^{5}$ South China Sea Fisheries Research \\ Institute, Chinese Academy of Fishery Sciences, Guangzhou, China, ${ }^{6}$ College of Resources, Environment and Planning, \\ Dezhou University, Dezhou, China
}

Seagrass beds provide nursery habitats for marine species. Seagrass leaves, in particular, are used as spawning grounds and as a food source for fish and invertebrates, but direct evidence of spawning in seagrass leaves is rare. It is also very challenging to identify eggs through morphological analysis, since the eggs of many marine species appear similar. To accurately identify the eggs on the leaves of the dominant seagrass species in the South China Sea, and evaluate seasonal contribution of seagrass leaves as a food source, DNA barcoding and stable isotope technique were conducted. Interestingly, Monetaria annulus was found to spawn on the leaf sheath of Thalassia hemprichii in Li'an gang, Hainan Island. This choice of oviposition site might increase embryo survival compared to the other parts of the seagrass leaves. Meanwhile, the eggs of Stethojulis trilineata were deposited on the entire leaf of Halophila ovalis in Liusha Bay, Guangdong Province. The small fingernail-shaped leaves of $H$. ovalis might be beneficial for $S$. trilineata to lay eggs as they are closer to the sediment surface than other seagrass leaves. Based on the stable carbon and nitrogen isotope analyses, the primary food source of $M$. annulus in summer and in winter were particulate organic matter and seagrass, respectively. The results suggest that seagrass leaves are not only important for fish and invertebrates as a spawning site, but also as a food source. The findings of the present study may support the urgent requirement of the conservation of seagrass beds for sustaining the productivity of marine fisheries.

Keywords: seagrass, eggs, DNA barcoding, spawning grounds, food source

\section{INTRODUCTION}

Seagrass beds are highly productive ecosystems that play pivotal ecological functions. The structurally complex seagrass beds not only provide abundant food sources to fish and invertebrates, but also serve as an important habitat for nursing, refuging, and spawning (Hemminga et al., 2000; Dorenbosch et al., 2006; Pogoreutz et al., 2012; 
Bertelli and Unsworth, 2014; Chacin and Stallings, 2016; Scott et al., 2018). For example, several studies have shown that fish abundance and invertebrate eggs density were significantly higher in seagrass areas than in sandy areas (Polte and Asmus, 2006; Simon and Levitan, 2011; Bertelli and Unsworth, 2014). Other fish also preferred spawning in Zostera marina beds over spawning in other habitats (Ivanova et al., 2016). In addition, juvenile shrimp and spiny lobsters migrate into seagrass beds for refuge from distant offshore spawning grounds (Hook et al., 1988). Seagrass leaves are an excellent substrate for diverse epiphytic organisms, including algae, fungi, protozoa, sponges, bryozoans, hydroids, and ascidians. These organisms are an integral component of seagrass ecosystems (Borowitzka et al., 2007). Different seagrass species show various morphologies ranging from the strap-shaped leaves of Thalassia, Posidonia, and Zostera to species with fingernail-shaped leaves such as Halophila (Borowitzka et al., 2007). Therefore, different marine species may attach on different seagrass leaves.

Seagrass leaves are also suitable spawning grounds for fish and invertebrates. For instance, herrings on the pacific coast of the United States deposit their eggs on the blades of $Z$. marina (Hook et al., 1988). Meanwhile, leaf sheaths of seagrasses contribute substantially to biomass (Manzanera et al., 1998), and play a pivotal role in nutrient acquisition (Zhang et al., 2011). For land plants such as wheat, insect eggs are always oviposited on the leaf blades rather than the leaf sheath, which could be related to the distribution of stimulatory chemicals on plant surfaces (Kanno and Harris, 2000). In contrast, insects deposit eggs on leaf sheaths of other plant species (e.g., rice and Spartina spp.) (Pfeiffer and Wiegert, 1981; Stout et al., 2002; Lanka et al., 2013). However, no studies reported whether the leaf sheath of seagrass, the only marine angiosperm, could be the oviposition site for marine species.

The eggs of marine species on seagrass leaves are relatively difficult to discover and are easily ignored. Because many species have similar egg sizes and morphology (Hofmann et al., 2017), it is very challenging to accurately identify eggs to the species level on seagrass leaves based on morphology. Moreover, egg color of the same species is also inconsistent, for example it may change from yellow to violet during the brooding period (Katoh, 1989; Villamor, 2015). Accurate identification of marine fish and invertebrates and their eggs is crucial to assist in managing fisheries for long-term sustainability and to improve ecosystem research (Ward et al., 2005). The DNA barcoding technique has been widely used for the genetic identification of fish species and their eggs (Ward et al., 2005, 2010; Radulovici et al., 2010; Azmir et al., 2017; Hou et al., 2017; Chen et al., 2018). The Fish Barcode of Life (FISH-BOL) campaign has been established to create a standardized reference DNA library based on the mitochondrial cytochrome oxidase subunit I gene (COI barcode) for all fish (Ward et al., 2010; Hardy et al., 2011). In addition, DNA barcoding has been used to identify seagrass species in the gut of a marine herbivorous fish and in sediments (Chelsky et al., 2011; Lucas et al., 2012; Mazzuca et al., 2013; Osathanunkul et al., 2015a,b; Hamaguchi et al., 2018). Genetic barcoding has only been used to correct fish species identification in the mangroveseagrass-coral reef continuum (Berkström et al., 2013) and to reveal the species composition of parrotfish juveniles in the seagrass beds of the Ryukyu Islands, Southern Japan (Ogawa et al., 2015). The application of the DNA barcoding technique to identify eggs of fish and invertebrates in wetland ecosystems, especially on the leaves of the seagrasses, has not been reported.

In this study, the DNA barcoding technique was used to identify the adhered eggs on the leaves of the dominant seagrass species, including Halophila ovalis, Thalassia hemprichii, and Enhalus acoroides, in the South China Sea. Stable carbon and nitrogen isotope analyses were also conducted to evaluate the dietary contribution of seagrass to identified species during summer and winter seasons. We hypothesized that: (1) the leaf sheath of seagrass is an important oviposition site for eggs of marine species due to the shelter it provides and (2) the dietary contribution of seagrass to the identified species is substantial and shows seasonal variation. This study verifies the function of seagrass leaves as an important spawning ground and food source for marine species, and enhances the understanding that is needed to improve the conservation of seagrass beds and the management of coastal fishery resources.

\section{MATERIALS AND METHODS}

The adhered suspected eggs on the seagrass leaves were sampled from the seagrass bed in Liusha Bay (Guangdong Province), Li'an gang, and Xincun Bay (Hainan Island) (Figure 1). Liusha Bay is a semi-closed bay with a 900-ha mixed seagrass bed. The seagrass species include $H$. ovalis, Halophila beccarii, and Halodule uninervis (Huang et al., 2006). Fish farming and shrimp-pond culture prevail in Liusha Bay. Li'an gang and Xincun Bay are both semi-closed bays with 320-ha and 200-ha mixed seagrass beds, respectively; the seagrass species include T. hemprichii, E. acoroides, Cymodocea rotundata, and H. ovalis (Huang et al., 2006). Fish farming in Li'an gang and Xincun Bay both began in the 1980s and they have become a demonstration base of marine aquaculture in China.

During sampling, only suspected eggs on one shoot of $H$. ovalis in Liusha Bay, T. hemprichii in Li'an gang, and E. acoroides in Xincun Bay were sampled on 8th December 2018, 12th January 2019, and 26th April 2019, respectively. The collected samples were preserved in $70 \%$ ethanol and stored at $-20^{\circ} \mathrm{C}$. In the laboratory, the egg specimens were sorted and photographed using a stereoscopic microscope and digital camera (Leica M 165C). They were identified using molecular biology analytical methods after triplicate egg samples were carefully removed from each shoot of seagrass by sterile dissecting needles. However, we only got successful identification for one, two, and three egg samples from $H$. ovalis, T. hemprichii, and E. acoroides, respectively.

DNA extraction from samples was conducted using a genomic DNA kit for marine organisms (Tiangen Biotech, Beijing, China), following the manufacturer's instructions. A barcode region of $\sim 650$ base pairs (bp) of the mitochondrial gene COI was targeted and amplified with universal primers LCO1490 (5'-GGTCAACAAATCATAAAGATATTGG-3') and HCO2198 (5'-TAAACTTCAGGGTGACCAAAAAATCA-3') 


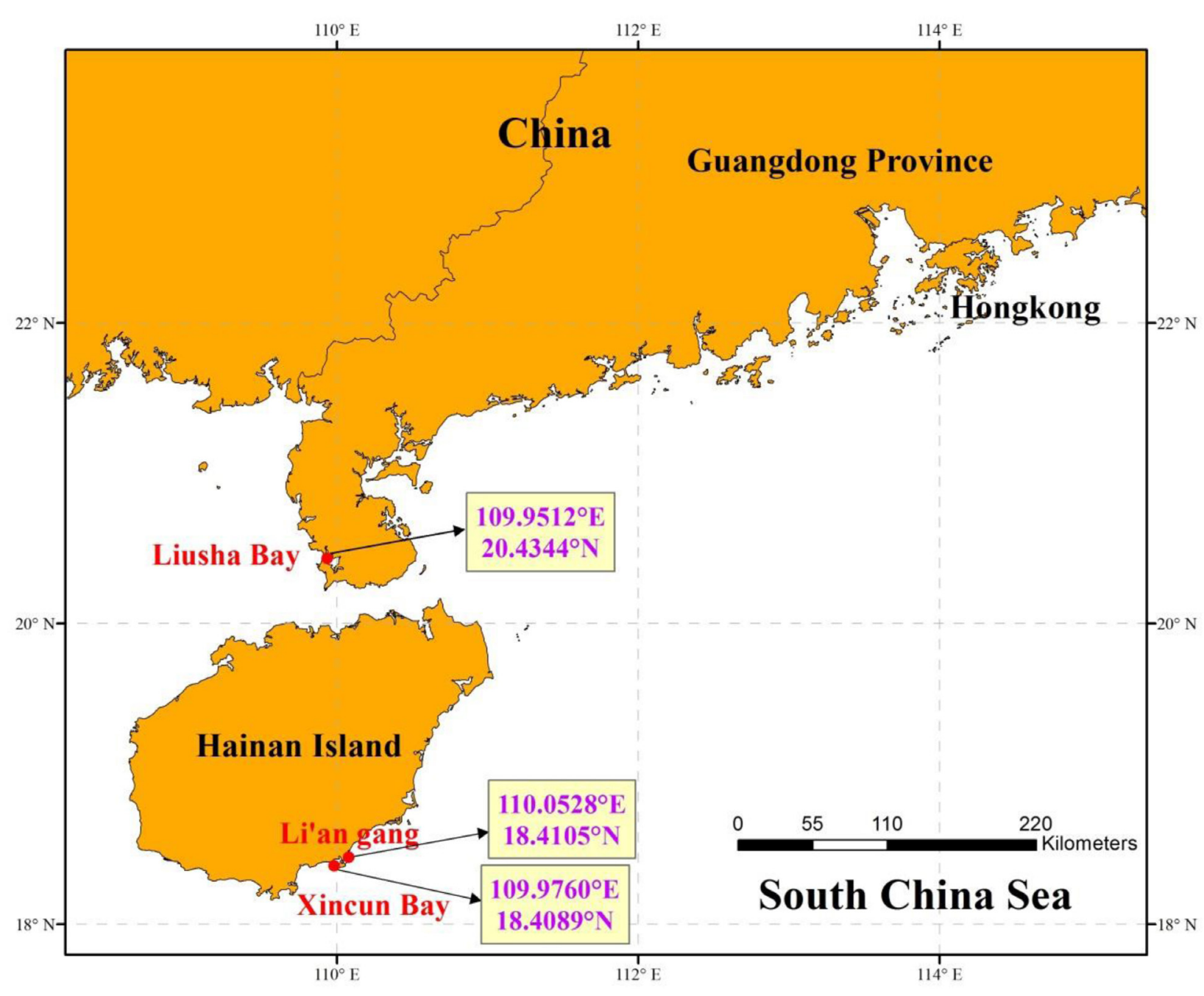

FIGURE 1 | The sampling locations in seagrass beds at Liusha Bay (Guangdong Province), Li'an gang, and Xincun Bay (Hainan Island).

(Folmer et al., 1994) in the PCR analyses. The $30 \mu \mathrm{L}$ PCR mix included $1.2 \mu \mathrm{L}(10 \mathrm{mM})$ of deoxyribonucleotide triphosphates (dNTPs) mix, $3 \mu \mathrm{L} 10 \times$ PCR buffer, $0.3 \mu \mathrm{L}\left(10 \mu \mathrm{mol} \mathrm{L}^{-1}\right)$ of each forward and reverse primer cocktail, $0.3 \mu \mathrm{L}$ Platinum Taq polymerase (Takara Biomedical Technology Inc), $23 \mu \mathrm{L}$ $\mathrm{ddH}_{2} \mathrm{O}$, and $2 \mu \mathrm{L}$ of DNA template. Specific cycle conditions used for PCR runs were: $3 \mathrm{~min}$ at $95^{\circ} \mathrm{C}$, followed by 35 cycles of $30 \mathrm{~s}$ at $95^{\circ} \mathrm{C}$; and $50 \mathrm{~s}$ at $50^{\circ} \mathrm{C}$, and $45 \mathrm{~s}$ at $68^{\circ} \mathrm{C}$, with a final extension of $10 \mathrm{~min}$ at $68^{\circ} \mathrm{C}$ (Applied Biosystems). PCR products were visualized in $1 \%$ agarose gel, and successful amplified samples were selected for sequencing. DNA sequencing was conducted using an automated DNA sequencing device 3500 (Life technologies ${ }^{1}$ ).

The consensus DNA sequences were checked visually and ambiguous ends were removed using the DNA Baser software $^{2}$ to confirm the correct base calling. Thereafter,

${ }^{1}$ www.lifetechnologies.com

${ }^{2}$ www.dnabaser.com all the trimmed sequences (c. 650bp) were compared with $\mathrm{NCBI}^{3}$ and Barcode of Life Data $\left(\mathrm{BOLD}^{4}\right)$ databases for sample identification using the basic local-alignment search tool (BLAST) and BOLD Identification tool, respectively (Table 1). We identified specimens to the species level if the similarity values were greater than $99 \%$. Sequence data for specimens were submitted to NCBI with the accession numbers as MN026918MN026923. The original sager sequences information, images, and geographic location of all samples were publically available in the FigShare ${ }^{5}$ with the DOI 10.6084/m9.figshare.11369202 and 10.6084/m9.figshare.11363195.

Duplicated samples of adult identified species in Li'an gang were collected in both summer (August, 2018) and winter (January, 2019). The potential food sources including seagrass, epiphyte, macroalgae, particulate organic matter (POM), and

\footnotetext{
${ }^{3}$ https://blast.ncbi.nlm.nih.gov

${ }^{4}$ www.boldsystems.org

${ }^{5}$ https://figshare.com
} 
TABLE 1 | List of the partial sequences of COI gene with sample ID, species, and origin of samples.

\begin{tabular}{ll}
\hline $\begin{array}{l}\text { Sample } \\
\text { ID/Species }\end{array}$ & Origin of samples (NCBI and/or BOLD*) \\
\hline LSB-1 & MN026918 (This study) \\
Stethojulis trilineata & EU871681; EU871682; KF264566 \\
LAG-1 & MN026919 (This study) \\
LAG-2 & AY161638; DQ206995; DQ206998; DQ206999; \\
Monetaria annulus & DQ324060; KT754015; LC469295 \\
& MN026921 (This study) \\
XCB-1 & MN026922 (This study) \\
XCB-2 & MN026923 (This study) \\
XCB-3 & HF548559; ICASC049-16*; KT693199; KT693201 \\
Botrylloides nigrum &
\end{tabular}

LSB, LAG and XCB represented the samples collected in the leaves of Halophila ovalis in Liusha Bay (Guangdong Province), Thalassia hemprichii in Li'an gang and Enhalus acoroides in Xincun Bay (Hainan Island), respectively. *Represented reference sequence only deposited in the BOLD.

sediment organic matter (SOM) were also sampled in both seasons. Four replicate samples were collected for each food source, except for macroalgae, with duplicate samples. During the low tide, the leaves of seagrass and macroalgae (Ulva lactuca) were collected. The top $1 \mathrm{~cm}$ sediment was collected using a spade for isotope analysis of SOM. During the high tide, POM was collected on a pre-burned (at $450^{\circ} \mathrm{C}$ for $3 \mathrm{~h}$ ) Whatman GF/F membrane. All the samples were stored frozen and processed as soon as possible.

In the laboratory, the epiphyte on the surface of seagrass leaves were scraped off with a scalpel; the seagrass leaves and macroalgae were washed several times with distilled water to remove debris. $\mathrm{POM}$ and SOM were acidified with $1 \mathrm{M}$ hydrochloric acid to remove carbonate. The acidified POM and SOM, seagrass leaves, epiphyte, macroalgae, and the identified animals were dried in an oven at $60^{\circ} \mathrm{C}(48 \mathrm{~h})$, ground, and sieved (120 mesh), placed in a $5 \mathrm{~mL}$ centrifuge tube, and stored dry. The $\delta^{13} \mathrm{C}$ and $\delta^{15} \mathrm{~N}$ isotopes were analyzed by a continuous-flow isotope-ratio mass spectrometer (Delta V Advantage, Thermo Fisher Scientific, Waltham, MA, United States). $\delta^{13} \mathrm{C}$ or $\delta^{15} \mathrm{~N}$ $(\%)=\left(\mathrm{R}_{\text {sample }} / \mathrm{R}_{\text {standard }}{ }^{-1}\right) \times 1000$, where $\mathrm{R}$ is the ratio of ${ }^{13} \mathrm{C} /{ }^{12} \mathrm{C}$ or ${ }^{15} \mathrm{~N} /{ }^{14} \mathrm{~N}$. The reference standard for carbon was Vienna PeeDee Belemnite, while the reference standard for nitrogen was atmospheric $\mathrm{N}_{2}$. The contribution of food sources was evaluated with a Bayesian modeling framework using SIMMR software (Parnell et al., 2013).

\section{RESULTS AND DISCUSSION}

With the application of the DNA barcoding method, we firstly found that there were eggs of fish and sea snail on the leaves of H. ovalis (Figure 2) and T. hemprichii (Figure 3), respectively, while the suspected eggs on the leaf of $E$. acoroides were one kind of sea squirt, named Botrylloides nigrum (Figure 4). The eggs on the leaves of $H$. ovalis were Stethojulis trilineata (Table 1 and Figure 2), with the density as 1267 ind/shoot. S. trilineata has also been observed in tropical southeast Asian seagrass beds

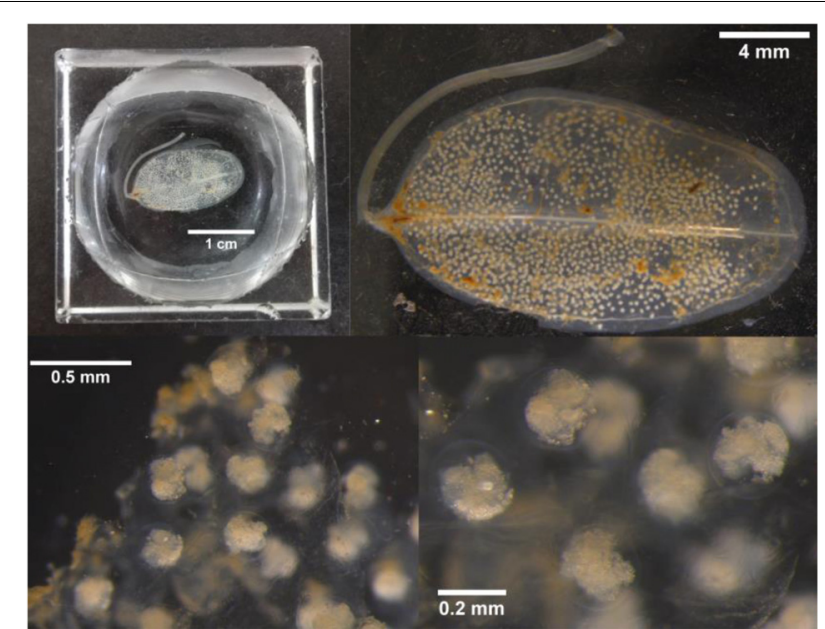

FIGURE 2 | The eggs of Stethojulis trilineata attaching on the leaf of Halophila ovalis with different scales collected from Liusha Bay, Guangdong Province.

(Pogoreutz et al., 2012; Noonsang et al., 2016), and showed a significant reduction with increasing distance from seagrass beds (van Schie, 2016). The smaller leaves of $H$. ovalis may not be an ideal surface for egg deposition in comparison with that of $T$. hemprichii. However, the small fingernail-shaped leaf of $H$. ovalis is relatively closer to the sediment surface, which might make it beneficial for $S$. trilineata to lay eggs on them. S. trilineata is distributed in the Indo-West Pacific region. The abundance of $S$. trilineata was about $0.2 \pm 1.0 \mathrm{ind} / 100 \mathrm{~m}^{2}$ in the seagrass bed in Barrang Lompo South in the Spermonde Archipelago, Indonesia (Pogoreutz et al., 2012). The adult fish of S. trilineata often inhabit coral reefs, while the juveniles are commonly found in tide pools or in lagoons. Simultaneously, many coral reef fish exhibit habitat partitioning throughout their lifetimes, using seagrass beds as nurseries (Jaxion-Harm et al., 2012; Sambrook et al., 2019). Seagrass beds may provide a better environment for fish to spawn and protect juveniles than coral reefs (Sambrook et al., 2019).

Monetaria annulus eggs (61 ind/shoot) were adhered to the leaf sheath of $T$. hemprichii (Table 1 and Figure 3). Actually, adult $M$. annulus are often seen on the leaves of $T$. hemprichii and sediment surface in seagrass bed at Li'an gang (Supplementary Figure S1). M. annulus was also the dominant sedentary grazer on T. hemprichii leaves in South Mozambique (Villamor, 2015). The abundance of $M$. annulus in seagrass beds at Li'an gang was $3 \pm 1 \mathrm{ind} / \mathrm{m}^{2}$. Similarly, the density of M. annulus in Sulangan Island, Nogas Island, and Olango Island, Philippines, were $8.4 \pm 0.3 \mathrm{ind} / \mathrm{m}^{2}, 4.4 \pm 10.6 \mathrm{ind} / \mathrm{m}^{2}$, and $0.01 \pm 0.003 \mathrm{ind} / \mathrm{m}^{2}$, respectively (Villamor and Yamamoto, 2015). M. annulus is one of the most common species in the family Cypraeidae, which is widely distributed in the IndoWest Pacific from tropical to temperate areas (Villamor, 2015; Leopardas et al., 2016). In the tropical area, M. annulus is usually found in sandy-rocky and sandy-muddy flat coasts covered with coral rubbles or seagrass, while the boulders in the rough coasts and coral rubbles are essential for the presence of this species in 


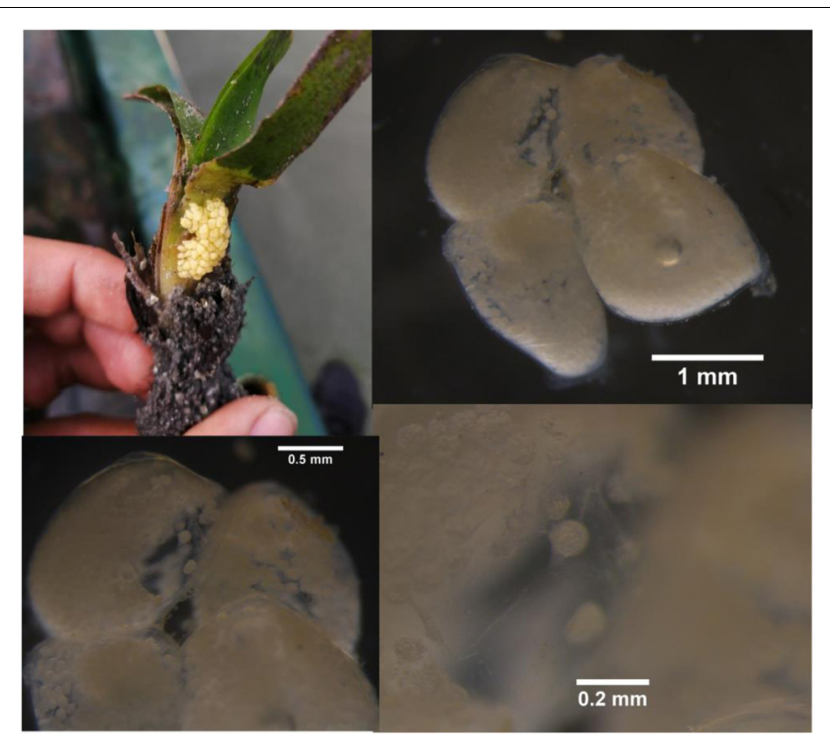

FIGURE 3 | The eggs of Monetaria annulus attaching on the leaf sheath of Thalassia hemprichii with different scales collected from Li'an gang, Hainan Island.

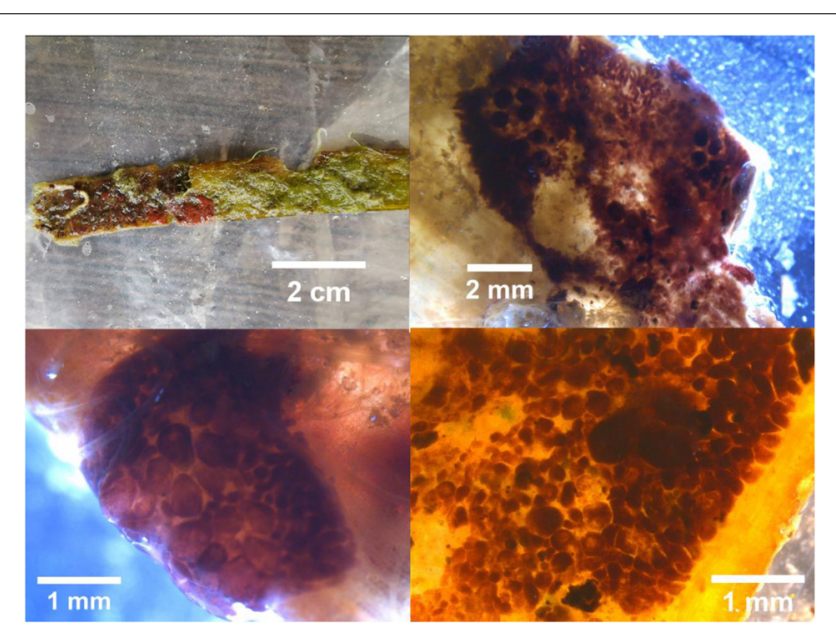

FIGURE 4 | Botrylloides nigrum attaching on the leaf of Enhalus acoroides with different scales collected from Xincun Bay, Hainan Island.

temperate and sub-tropical areas, respectively (Villamor, 2015). There was a low proportion or absence of immature cowries in the habitat shared with adults (Villamor and Yamamoto, 2015). Interestingly, the leaf sheath of T. hemprichii was also a spawning ground for invertebrates. The translucent egg capsule of $S$. bryanae has also been found on the leaf basal section of H. hawaiiana (Unabia, 2011). A large number of species have a specific oviposition behavior as they select a narrow range of plant species as well as particular parts of a plant (Ganehiarachchi et al., 2013). This could be explained by the hypothesis of maximizing embryo survival. Females choose oviposition sites that minimize predation risk, maintain a microclimate suitable for embryo development, or avoid habitats prone to desiccation in aquatic

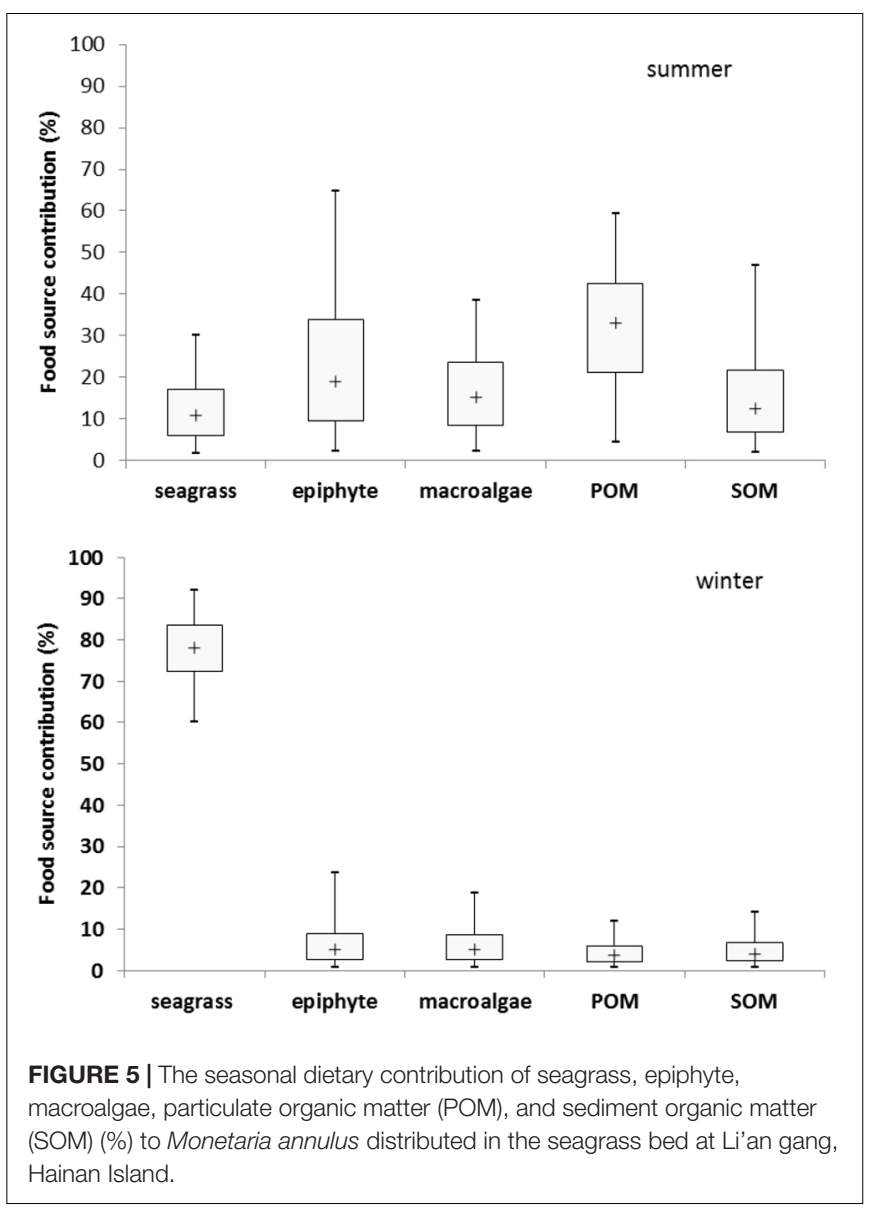

species (Refsnider and Janzen, 2010). The leaf sheath is lower and more sheltered than the other parts of the leaf. Laying eggs on the leaf sheath of $T$. hemprichii may maximize embryo survival since eggs on the leaf sheath would be more protected from predation, or being washed away by currents or waves (Refsnider and Janzen, 2010). Furthermore, eggs attached to the leaf sheath might be more protected from desiccation (Polte and Asmus, 2006), since seagrass leaves bend to create a suitable microenvironment for the leaf sheath to avoid the stress of direct sunlight, high temperature, and fast desiccation during low tide.

Based on the analysis of stable carbon and nitrogen isotopes, results indicated that the potential dietary contribution of seagrass, epiphyte, macroalgae, POM and SOM to the adult $M$. annulus in summer were $1.7-30.2 \%, 2.2-64.8 \%$, $2.2-38.4 \%, 4.4-59.4 \%$, and $1.9-46.9 \%$, respectively, with the corresponding median values as $10.8,19.1,15.2,33$, and $12.5 \%$, respectively. However, the dietary contribution of seagrass, epiphyte, macroalgae, POM and SOM to the adult M. annulus in winter were $60-91.9 \%, 0.7-23.5 \%, 0.7-18.8 \%, 0.6-11.8 \%$, and $0.7-14.1 \%$, respectively, with the corresponding median values as 78.1, 5.1, 5.0, 3.6, and 4.1\%, respectively (Figure 5). Interestingly, POM was the main food source for $M$. annulus in summer, while seagrass was the primary food source in winter. Shoot density of T. hemprichii is the highest in summer and lowest in winter (Xu et al., 2009). Leaves of T. hemprichii fall during winter, resulting 


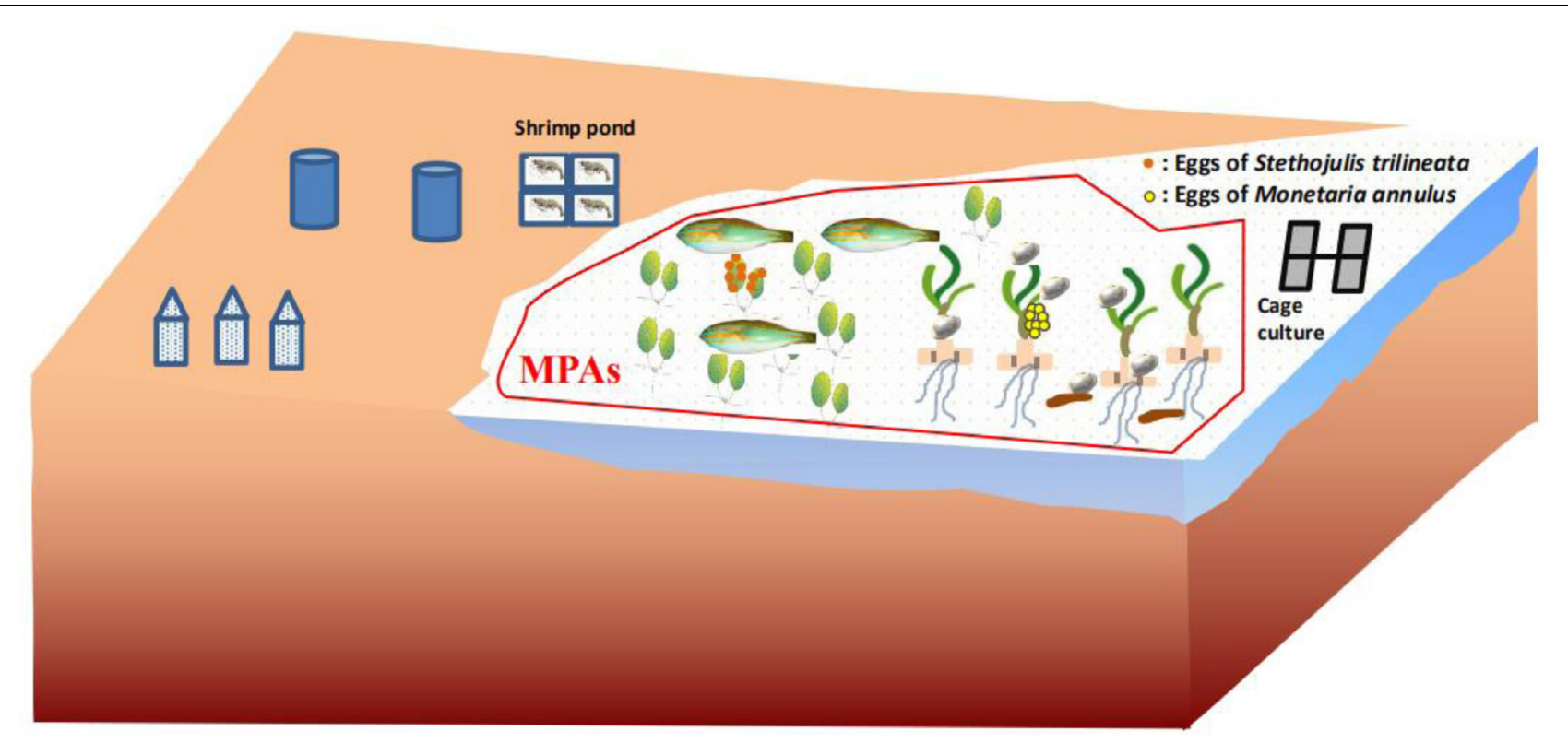

FIGURE 6 | Schematic diagram of seagrass leaves as spawning grounds and food source for marine species and Marine Protective Areas (MPAs).
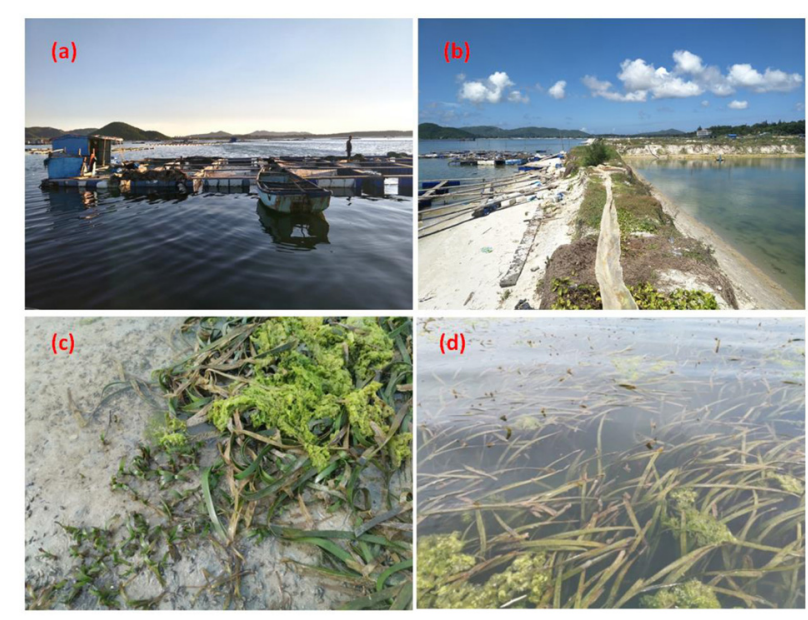

(d)

FIGURE 7 | The threats including fish caging (a), shrimp pond culture (b), and macroalgae bloom (c,d) in seagrass beds in Li'an gang, Hainan Island.

in higher leaf detritus in the seagrass bed. M. annulus could also utilize the decomposed leaf detritus as a food source to a large extent. Thus, T. hemprichii not only provides substrate for M. annulus to deposit eggs, but it is also an important food source for this species, especially in winter. Similarly, Smaragdia bryanae, an endemic Hawaiian gastropod, is a specialized marine herbivore that uses the endemic seagrass Halophila hawaiiana as both food source and habitat (Unabia, 2011).

The present study directly proved that seagrass leaves are an important spawning ground and food source for fish and invertebrates (Figure 6), contributing to supporting regional fishery productivity. This undiscovered ecological function of seagrass leaves should be vigorously promoted to government managers, local fisherman, and students. T. hemprichii and $H$. ovalis in particular should be a priority for protection, because they are the dominant species in the tropical area of the South China Sea. However, seagrass beds in the South China Sea have been seriously impacted by human activities (Huang et al., 2006; Jiang et al., 2017). For example, increasing human disturbances such as fish-cage culture, shrimp-pond culture, shellfish collection, and so on has caused the seagrass bed in Li'an gang (Figure 7), Xincun Bay, and Liusha Bay, to decrease by 80,25 , and 47.4 ha, respectively (unpublished data). This undoubtedly results in a lower availability of nursery habitat (Olney and Boehlert, 1988) and substrate for egg deposition. Human disturbance such as reclamation, shellfish collection, fish-cage culture, and shrimp-pond culture should be reduced or prohibited. Furthermore, marine protective areas (MPAs) should also be established to preserve these precious habitats. The sites preferred by cowries and fish, and especially nursery grounds where immature M. annulus, S. trilineata (Figure 5), and other marine species can be sheltered should be established MPAs (Villamor and Yamamoto, 2015). Fortunately, the local government has built up Seagrass Special Protected Areas in places including Li'an gang and Xincun Bay and carried out the "Blue Bay Rehabilitation" project, with the expectation that the declining trend of seagrass beds will be reversed. MPAs should be also established for protecting seagrass beds in Liusha Bay. Ecosystem-level management of these shallow water habitats are also required to conserve fish assemblages (Unsworth et al., 2008). We also propose that limiting the quantity of gastropod harvest is an effective way to conserve $M$. annulus in fisheries, since overexploitation by humans undoubtedly leads to low density. Community-based fisheries and aquatic resource management council can be organized among fishermen who 
can cooperate in regulating harvest (Villamor, 2015). Seagrass restoration is also urgently needed to resume its function as spawning grounds and food source.

In summary, fish and gastropod spawn on the seagrass leaves, and the leaf sheath is also an important oviposition site for eggs of marine species. Furthermore, the eggs deposited on various seagrass leaf parts are yet to be identified using DNA barcoding methods, which may reveal many other species that use seagrass leaves as a spawning ground. Eutrophication and other environmental disturbances would be expected to alter the carbon and nitrogen metabolism in seagrass, which may change the morphology and metabolomics (Invers et al., 2004). Further studies are needed to investigate whether this alteration affects the attachment of eggs on the seagrass leaves. Meanwhile, the dietary contribution of seagrass to marine species was substantial and showed higher value in winter than in summer. Does the dietary contribution of seagrass also change for key marine species at different growth stages? This needs further and systematic research using stable carbon and nitrogen isotopes. Furthermore, further studies are needed to investigate the ontogenetic shift patterns of marine species among habitats including seagrass beds, coral reefs, and mangroves. The connectivity among these habitats at a species level should be taken into consideration when implementing policy and conservation practices (Jaxion-Harm et al., 2012).

\section{DATA AVAILABILITY STATEMENT}

Sequence data for specimens were submitted to NCBI with the accession numbers as MN026918-MN026923. The original sager sequences information, images and geographic location of all samples were publically available in the FigShare (https://figshare.com) with the DOI 10.6084/m9.figshare.11369202 and 10.6084/m9.figshare. 11363195 .

\section{REFERENCES}

Azmir, I. A., Esa, Y., Amin, S. M. N., Yasin, I. S. M., and Yusof, F. Z. M. (2017). Identification of larval fish in mangrove areas of Peninsular Malaysia using morphology and DNA barcoding methods. J. Appl. Ichthyol. 33, 998-1006. doi: $10.1111 /$ jai.13425

Berkström, C., Jörgensen, T. L., and Hellström, M. (2013). Ecological connectivity and niche differentiation between two closely related fish species in the mangrove-seagrass-coral reef continuum. Mar. Ecol. Prog. Ser. 477, 201-215. doi: $10.3354 /$ meps 10171

Bertelli, C. M., and Unsworth, R. K. F. (2014). Protecting the hand that feeds us: seagrass (Zostera marina) serves as commercial juvenile fish habitat. Mar. Pollut. Bull. 83, 425-429. doi: 10.1016/j.marpolbul.2013.08.011

Borowitzka, M. A., Lavery, P. S., and Van Keulen, M. (2007). "Epiphytes of seagrasses," in Seagrasses: Biology, Ecologyand Conservation, eds A. W. Larkum, R. R. J. Orth, and C. M. Duarte (Dordrecht: Springer), 441-461.

Chacin, D. H., and Stallings, C. D. (2016). Disentangling fine- and broad- scale effects of habitat on predator-prey interactions. J. Exp. Mar. Biol. Ecol. 483, 10-19. doi: 10.1016/j.jembe.2016.05.008

Chelsky, B. A., Burfeind, D. D., Loh, W. K., and Tibbetts, I. R. (2011). Identification of seagrasses in the gut of a marine herbivorous fish using DNA barcoding and

\section{ETHICS STATEMENT}

The animal study was reviewed and approved by the South China Sea Institute of Oceanology, Chinese Academy of Sciences.

\section{AUTHOR CONTRIBUTIONS}

ZJ designed the work, analyzed the data, and wrote the manuscript. DH performed the DNA barcoding analysis and wrote the manuscript. YF participated in the design of the work and collected the samples in the field. LC collected the samples and analyzed isotope carbon and nitrogen. CZ, SL, YW, QC, CR, and $\mathrm{JH}$ collected the samples. $\mathrm{XH}$ participated in the work design and approved the final version.

\section{FUNDING}

This research was supported by the National Natural Science Foundation of China (nos. 41730529 and 41976144), Key Special Project for Introduced Talents Team of Southern Marine Science and Engineering Guangdong Laboratory (Guangzhou) (GML2019ZD0405), the Natural Science Fund of Guangdong (2019A1515010552), the National Key Research and Development Program of China (2017YFC0506104), the National Specialized Project of Science and Technology (2015FY110600), and the Innovation Academy of South China Sea Ecology and Environmental Engineering, Chinese Academy of Sciences (ISEE2018PY01 and ISEE2018ZD02).

\section{SUPPLEMENTARY MATERIAL}

The Supplementary Material for this article can be found online at: https://www.frontiersin.org/articles/10.3389/fmars. 2020.00194/full\#supplementary-material

visual inspection techniques. J. Fish Biol. 79, 112-121. doi: 10.1111/j.1095-8649. 2011.02999.x

Chen, Y., He, P., and Yang, J. (2018). Molecular identification of fish eggs in Enteromopha of Rudong sea area based on DNA barcode. J. Shanhai. Ocean. Univ. 27, 1-7. doi: 10.12024/jsou.20170301981

Dorenbosch, M., Grol, M. G. G., Nagelkerken, I., and Van Der Velde, G. (2006). Seagrass beds and mangroves as potential nurseries for the threatened Indo-Pacific humphead wrasse, Cheilinus undulatus and Caribbean rainbow parrotfish, Scarus guacamaia. Biol. Conserv. 129, 277-282. doi: 10.1016/j. biocon.2005.10.032

Folmer, O., Black, M., Hoeh, W., Lutz, R., and Vrijenhoek, R. (1994). DNA primers for amplification of mitochondrial cytochrome $c$ oxidase subunit I from diverse metazoan invertebrates. Mol. Mar. Biol. Biotechnol. 3, 294-299.

Ganehiarachchi, G., Anderson, K. M., Harmon, J., and Harris, M. O. (2013). Why oviposit there? Fitness consequences of a gall midge choosing the plant's youngest leaf. Environ. Entomol. 42, 123-130. doi: 10.1603/EN12213

Hamaguchi, M., Shimabukuro, H., Hori, M., Yoshida, G., Terada, T., and Miyajima, T. (2018). Quantitative real-time polymerase chain reaction (PCR) and droplet digital PCR duplex assays for detecting Zostera marina DNA in coastal sediments. Limnol. Oceanogr. Methods 16, 253-264. doi: 10.1002/lom3. 10242 
Hardy, C. M., Adams, M., Jerry, D. R., Court, L. N., Morgan, M. J., and Hartley, D. M. (2011). DNA barcoding to support conservation: species identification, genetic structure and biogeography of fishes in the Murray-Darling River Basin, Australia. Mar. Freshwat. Res. 62, 887-901. doi: 10.1071/MF 11027

Hemminga, M., Hemminga, M. A., and Duarte, C. M. (2000). Seagrass Ecology. Cambridge: Cambridge University Press.

Hofmann, T., Knebelsberger, T., Kloppmann, M., Ulleweit, J., and Raupach, M. J. (2017). Egg identification of three economical important fish species using DNA barcoding in comparison to a morphological determination. J. Appl. Ichthyol. 33, 925-932. doi: 10.1111/jai.13389

Hook, D. D., Mckee, K. Jr., Smith, H. K., Gregory, J., Burrel, V. G. Jr., Devoe, M. R., et al. (1988). The Ecology and Management of Wetlands: Volume 1: Ecology of Wetlands. Berlin: Springer Science \& Business Media.

Hou, G., Chen, W. T., Lu, H. S., Cheng, F., and Xie, S. G. (2017). Developing a DNA barcode library for perciform fishes in the South China Sea: species identification, accuracy and cryptic diversity. Mol. Ecol. Resour. 18, 137-146. doi: 10.1111/1755-0998.12718

Huang, X., Huang, L., Li, Y., Xu, Z., Fong, C., Huang, D., et al. (2006). Main seagrass beds and threats to their habitats in the coastal sea of South China. Chin. Sci. Bull. 51, 136-142. doi: 10.1007/s11434-006-9136-5

Invers, O., Kraemer, G. P., Pérez, M., and Romero, J. (2004). Effects of nitrogen addition on nitrogen metabolism and carbon reserves in the temperate seagrass Posidonia oceanica. J. Exp. Mar. Biol. Ecol. 303, 97-114. doi: 10.1016/j.jembe. 2003.11.005

Ivanova, T., Ivanov, M., Golovin, P., Polyakova, N., and Lajus, D. (2016). The White Sea threespine stickleback population: spawning habitats, mortality, and abundance. Evol. Ecol. Res. 17, 301-315. doi: 10.1046/j.1570-7458.2000.00680.x

Jaxion-Harm, J., Saunders, J., and Speight, M. R. (2012). Distribution of fish in seagrass, mangroves and coral reefs: life-stage dependent habitat use in Honduras. Rev. Biol. Trop. 60, 683-698. doi: 10.15517/rbt.v60i2. 3984

Jiang, Z., Liu, S., Zhang, J., Zhao, C., Wu, Y., Yu, S., et al. (2017). Newly discovered seagrass beds and their potential for blue carbon in the coastal seas of Hainan Island, South China Sea. Mar. Pollut. Bull. 125, 513-521. doi: 10.1016/j.marpolbul.2017.07.066

Kanno, H., and Harris, M. (2000). Physical features of grass leaves influence the placement of eggs within the plant by the Hessian fly. Entomol. Exp. Appl. 96, 69-80.

Katoh, M. (1989). Life history of the golden ring cowry Cypraea annulus (Mollusca: Gastropoda) on Okinawa Island, Japan. Mar. Biol. 101, 227-234. doi: 10.1007/ bf00391462

Lanka, S., Ottea, J., Beuzelin, J., and Stout, M. (2013). Effects of chlorantraniliprole and thiamethoxam rice seed treatments on egg numbers and first instar survival of Lissorhoptrus oryzophilus (Coleoptera: Curculionidae). J. Econ. Entomol. 106, 181-188. doi: 10.1603/EC12282

Leopardas, V., Honda, K., Go, G. A., Bolisay, K., Pantallano, A. D., Uy, W., et al. (2016). Variation in macrofaunal communities of seagrass beds along a pollution gradient in Bolinao, northwestern Philippines. Mar. Pollut. Bull. 105, 310-318. doi: 10.1016/j.marpolbul.2016.02.004

Lucas, C., Thangaradjou, T., and Papenbrock, J. (2012). Development of a DNA barcoding system for seagrasses: successful but not simple. PLoS One 7:e29987. doi: 10.1371/journal.pone.0029987

Manzanera, M., Alcoverro, T., and Romero, J. (1998). The role of the remnant leaf sheaths (scales) attached to the Posidonia oceanica (L.) Delile rhizomes. J. Exp. Mar. Biol. Ecol. 223, 257-270. doi: 10.1016/S0022-0981(97)00184-6

Mazzuca, S., Bjork, M., Beer, S., Felisberto, P., Gobert, S., Procaccini, G., et al. (2013). Establishing research strategies, methodologies and technologies to link genomics and proteomics to seagrass productivity, community metabolism, and ecosystem carbon fluxes. Front. Plant. Sci. 4:38. doi: 10.3389/fpls.2013. 00038

Noonsang, P., Tina, F. W., Jaroensutasinee, M., Jaroensutasinee, K., Chumkiew, S., and Kuhapong, U. (2016). Diversity of coral reef fishes at Racha Yai Island, Thailand. Kasetsart Univ. Fish. Res. Bull. 40, 19-34.

Ogawa, N., Seki, S., Yamada, H., and Nakamura, Y. (2015). Development of a Japanese parrotfish species identification method using PCR-RFLP analysis and its application-Determination of the species composition of parrotfish juveniles in seagrass beds of the Ryukyu Islands, southern Japan. Aquacul. Sci. 63, 423-435. doi: 10.11233/aquaculturesci.63.423

Olney, J. E., and Boehlert, G. W. (1988). Nearshore ichthyoplankton associated with seagrass beds in the lower Chesapeake Bay. Mar. Ecol. Prog. Ser. 45, 33-43. doi: 10.3354/meps045033

Osathanunkul, M., Madesis, P., Ounjai, S., Suwannapoom, C., and Jampeetong, A. (2015a). Rapid discrimination between four seagrass species using hybrid analysis. Gen. Mol. Res. 14, 3957-3963. doi: 10.4238/2015.April.27.10

Osathanunkul, M., Suwannapoom, C., Singtonat, S., Poomipoo, N., Jampeetong, A., and Madesis, P. (2015b). Rapid analysis for the identification of the seagrass Halophila ovalis (Hydrocharitaceae). Afr. J. Biotechnol. 14, 649-656. doi: 10. 5897/AJB204.13855

Parnell, A. C., Phillips, D. L., Bearhop, S., Semmens, B. X., Ward, E. J., Moore, J. W., et al. (2013). Bayesian stable isotope mixing models. Environmetrics 24, 387-399. doi: 10.1002/env.2221

Pfeiffer, W. J., and Wiegert, R. (1981). "Grazers on Spartina and their predators," in The Ecology of a Salt Marsh, eds L. R. Pomeroy and R. G. Wiegert (Berline: Springer), 87-112.

Pogoreutz, C., Kneer, D., Litaay, M., Asmus, H., and Ahnelt, H. (2012). The influence of canopy structure and tidal level on fish assemblages in tropical Southeast Asian seagrass meadows. Estuar. Coast. Shelf Sci. 107, 58-68. doi: 10.1016/j.ecss.2012.04.022

Polte, P., and Asmus, H. (2006). Intertidal seagrass beds (Zostera noltii) as spawning grounds for transient fishes in the Wadden Sea. Mar. Ecol. Prog. Ser. 312, 235-243. doi: 10.3354/meps312235

Radulovici, A. E., Archambault, P., and Dufresne, F. (2010). DNA Barcodes for marine biodiversity: moving fast forward. Diversity 2, 450-472. doi: 10.3390/ d2040450

Refsnider, J. M., and Janzen, F. J. (2010). Putting eggs in one basket: ecological and evolutionary hypotheses for variation in oviposition-site choice. Annu. Rev. Ecol. Evol. 41, 39-57. doi: 10.1146/annurev-ecolsys-102209144712

Sambrook, K., Hoey, A. S., Andréfouët, S., Cumming, G. S., Duce, S., and Bonin, M. C. (2019). Beyond the reef: the widespread use of non-reef habitats by coral reef fishes. Fish Fish. 20, 903-920. doi: 10.1111/faf.12383

Scott, A. L., York, P. H., Duncan, C., Macreadie, P. I., Connolly, R. M., Ellis, M. T., et al. (2018). The role of herbivory in structuring tropical seagrass ecosystem service delivery. Front. Plant. Sci. 9:127. doi: 10.3389/fpls.2018. 00127

Simon, T. N., and Levitan, D. R. (2011). Measuring fertilization success of broadcast-spawning marine invertebrates within seagrass meadows. Biol. Bull. 220, 32-38. doi: 10.1086/BBLv220n1p32

Stout, M. J., Rita Riggio, M., Zou, L., and Roberts, R. (2002). Flooding influences ovipositional and feeding behavior of the rice water weevil (Coleoptera: Curculionidae). J. Econ. Entomol. 95, 715-721. doi: 10.1603/0022-0493-95.4. 715

Unabia, C. R. (2011). The snail Smaragdia bryanae (Neritopsina, Neritidae) is a specialist herbivore of the seagrass Halophila hawaiiana (Alismatidae, Hydrocharitaceae). Invertebr. Biol. 130, 100-114. doi: 10.1111/j.1744-7410. 2011.00225.x

Unsworth, R. K., De León, P. S., Garrard, S. L., Jompa, J., Smith, D. J., and Bell, J. J. (2008). High connectivity of Indo-Pacific seagrass fish assemblages with mangrove and coral reef habitats. Mar. Ecol. Prog. Ser. 353, 213-224. doi: $10.3354 /$ meps07199

van Schie, J. (2016). The Effectiveness of Marine Protected Areas In the southeastern part of Negros Oriental, Philippines. Philippines: Marine Conservation Philippines.

Villamor, S., and Yamamoto, T. (2015). Population characteristics of Monetaria annulus (Linnaeus, 1758)(Gastropoda: Cypraeidae) from temperate to tropical areas. Aquacul. Sci. 63, 273-282. doi: 10.11233/aquaculturesci. 63.273

Villamor, S. S. (2015). Ecology of Monetaria Annulus (Linnaeus, 1758)(Mollusca: Gastropoda: Cypraeidae) from Temperate to Tropical Areas. Kagoshima: Kagoshima University.

Ward, R., Zemlak, T., Innes, B., and Last, P. D. N. (2005). DNA barcoding Australia's fish species. Philos. Trans. R. Soc. Lond. B Biol. Sci. 360, 1847-1857. doi: $10.1098 /$ rstb.2005.1716 
Ward, R. D., Hanner, R. H., and Hebert, P. D. N. (2010). The campaign to DNA barcode all fishes, FISH-BOL. J. Fish Biol. 74, 329-356. doi: 10.1111/j.1095-8649. 2008.02080.x

Xu, Z. Z., Huang, L. M., Huang, X. P., Zhu, A. J., and Zhang, S. (2009). Growth strategy of seagrass Thalassia hemprichii in Xincun Bay near Hainan Island of China. Mar. Sci. Bull. 11, 53-61. doi: 10.3969/j.issn.1000-9620.2009.01.006

Zhang, J. P., Huang, X. P., Jiang, Z. J., and Thorhaug, A. (2011). Comparison of the role of the foliar sheath in nutrient (ammonium and phosphate) acquisition by the seagrass Thalassia hemprichii (Ehrenb.) Aschers. at two different sites on tropical Hainan Island, China. Hydrobiologia 669, 45-61. doi: 10.1007/s10750011-0662-z
Conflict of Interest: The authors declare that the research was conducted in the absence of any commercial or financial relationships that could be construed as a potential conflict of interest.

Copyright (c) 2020 Jiang, Huang, Fang, Cui, Zhao, Liu, Wu, Chen, Ranvilage, He and Huang. This is an open-access article distributed under the terms of the Creative Commons Attribution License (CC BY). The use, distribution or reproduction in other forums is permitted, provided the original author(s) and the copyright owner(s) are credited and that the original publication in this journal is cited, in accordance with accepted academic practice. No use, distribution or reproduction is permitted which does not comply with these terms. 